\title{
Mycobacterium tuberculosis DNA fingerprint clusters and its relationship with RDRio genotype in Brazil
}

\author{
Solange Alves Vinhas ${ }^{a}$, Moisés Palaci ${ }^{a}$, Hebert Silva Marques ${ }^{a}$, Paola Poloni Lobo de \\ Aguiar $^{a}$, Fabíola Karla Ribeiro ${ }^{a}$, Renata Lyrio Peres ${ }^{a}$, Reynaldo Dietze ${ }^{\mathrm{a}}$, Harrison Magdinier \\ Gomes $^{c}$, Philip Noel Suffys ${ }^{c}$, Jonathan E. Golub ${ }^{d}$, Lee W. Riley ${ }^{e}$, and Ethel Leonor Noia \\ Maciel $^{\mathrm{a}, \mathrm{b},{ }^{*}}$ \\ aNúcleo de Doenças Infecciosas, Universidade Federal do Espírito Santo, Av. Marechal Campos, \\ 1468 Maruípe, Vitória, ES, Brazil \\ bPrograma de Pós-graduação em Saúde Coletiva, Universidade Federal do Espírito Santo, Brazil \\ 'Laboratório de biologia Molecular Aplicada a Micobactérias, Instituto Oswaldo Cruz - FioCruz, \\ Rio de Janeiro, Brazil \\ dSchool of Medicine, Johns Hopkins University, Baltimore, MD, USA \\ eDivision of Infectious Disease and Vaccinology, School of Public Health, University of California, \\ Berkeley, CA, USA
}

\section{SUMMARY}

Mycobacterium tuberculosis (Mtb) strains designated as $\mathrm{RD}^{\text {Rio }}$ are responsible for a large cluster of new cases of tuberculosis (TB) in Rio de Janeiro. They were previously shown to be associated with severe manifestations of TB. Here, we used three genotyping methods (IS6110 RFLP, spoligotyping, and multiplex PCR) to characterize $\mathrm{RD}^{\mathrm{Rio}}$ and non- $\mathrm{RD}^{\mathrm{Rio}}$ strains from the metropolitan area of Vitória, State of Espirito Santo in southeast Brazil to determine strain diversity and transmission patterns. Strains with identical IS6110 RFLP patterns were considered to belong to a cluster indicative of recent transmission. Between 2000 and 2010, we identified 5470 new TB patients and genotyped 981 Mtb strains. Of these, 376 (38\%) were RD ${ }^{\text {Rio }}$. By RFLP, $180(48 \%)$ of $376 \mathrm{RD}^{\text {Rio }}$ strains and $235(40 \%)$ of 593 non-RD ${ }^{\text {Rio }}$ strains belonged to RFLP cluster pattern groups $(p=0.023)$. Simpson's diversity index based on RFLP patterns was 0.96 for $\mathrm{RD}^{\text {Rio }}$ and 0.98 for non-RD Rio strains. Thus, although $\mathrm{RD}^{\text {Rio }}$ strains appear to be comprised of a fewer number of RFLP genotypes, they represent a heterogeneous group. While TB cases caused by $\mathrm{RD}^{\text {Rio }}$ appear more likely to be due to recent transmission than cases caused by non-RD Rio strains, the difference is small. These observations suggest that factors other than inherent biological characteristic of $\mathrm{RD}^{\text {Rio }}$ lineages are more important in determining recent transmission, and that public health measures to interrupt new transmissions need to be emphasized for TB control in Vitória.

\section{Keywords}

Tuberculosis; DNA fingerprinting; Mycobacterium tuberculosis; Epidemiologic surveillance; $\mathrm{RD}^{\text {Rio }}$

\footnotetext{
(c) 2012 Elsevier Ltd. All rights reserved.

*Corresponding author. Núcleo de Doenças Infecciosas, Universidade Federal do Espírito Santo, Av. Marechal Campos, 1468 Maruípe, Vitória, ES, Brazil. Tel.: +55 279973 3123. emaciel@ndi.ufes.br, ethel.maciel@gmail.com (E.L.Noia Maciel).
} 


\section{Introduction}

In 2004, the Brazilian National Tuberculosis Control Program designated 315 cities as priority regions for surveillance, control and prevention of $\mathrm{TB},{ }^{1,2}$ including eight municipalities in the State of Espírito Santo, in southeastern Brazil. Despite efforts to improve the control program such as the introduction of directly observed therapy-short course (DOTS) and the family health program, the TB incidence has remained almost unchanged in Espírito Santo State over the past 10 years. ${ }^{1,3}$ One possible explanation could be that active case finding efforts to interrupt new transmissions in high-risk populations have been inadequate. Another possible explanation may be that there were undetected outbreaks or spread of some highly transmissible strains in the state. ${ }^{4}$

In 2000, in collaboration with the State Health Department, the University of Espírito Santo implemented a laboratory network to improve TB diagnosis through standardized training of laboratory personnel and utilization of culture for all suspected TB diagnoses. As part of this strategy an information system entitled "TB-Notes" was created based on Lotus Notes ${ }^{\mathrm{TM}}$. This network includes four municipalities that report $70 \%$ of TB cases in the state, including Vitória, the state capital.

In urban settings with highly mobile populations, studies have suggested that identical IS 6110 RFLP patterns in Mtb isolates from epidemiologically linked patients reflect TB resulting from recent transmission. ${ }^{5,6}$ Strains with IS6110 RFLP patterns that are identical or similar are said to belong to a cluster and represent recent transmission. In 2007, Lazzarini et al. reported the identification of Mtb strains from patients in Rio de Janeiro, Brazil that were characterized by a deletion of a $26.3-\mathrm{kb}$ region that included 10 genes and was referred to as $\mathrm{RD}^{\text {Rio }}$. It occurred exclusively among strains of the Latin American-Mediterranean (LAM) spoligotype family. ${ }^{7-9}$ The high prevalence in Rio de Janeiro of this $\mathrm{RD}^{\text {Rio }}$ lineage and its association with more severe disease and cavitary lung lesions suggested enhanced virulence and transmission of this lineage, and therefore its high local prevalence. ${ }^{7-9}$

However, previous studies have not demonstrated whether TB caused by $\mathrm{RD}^{\text {Rio }}$ strains is more likely to result from recent transmission or reactivation of an old infection. ${ }^{7-9}$ The $\mathrm{RD}^{\text {Rio }}$ designation is based on a multiplex PCR-based test. ${ }^{7,9}$ Strains given this designation actually belong to multiple genotypes by IS 6110 RFLP analysis. The present study was therefore undertaken to investigate whether $\mathrm{RD}^{\text {Rio }}$ strains in Vitória are any more likely than non- $\mathrm{RD}^{\mathrm{Rio}}$ strains to represent recent transmission by IS6110 RFLP analysis. If the proportion of $\mathrm{RD}^{\mathrm{Rio}}$ strains belonging to cluster RFLP patterns is similar to that for non$\mathrm{RD}^{\mathrm{Rio}}$ strains, then the high prevalence of $\mathrm{RD}^{\mathrm{Rio}}$ strains may represent recent introduction of these strains into the community and not necessarily their enhanced virulence.

\section{Materials and methods}

\subsection{Study design and patient data}

This was a retrospective, laboratory-based surveillance study of all new TB cases diagnosed in the metropolitan area of Vitória between 2000 and 2010. The metropolitan area comprises four municipalities (Vitória, Cariacica, Serra and Vila Velha) with about 1,200,000 inhabitants.

General epidemiologic characteristics including gender, age, geographic origin, HIV status, previous history of TB and drug-susceptibility profile were collected from laboratory records or medical files and also from the national surveillance system (SINAN). 
Countries which have financial resources recommend performing drug-susceptibility testing (DST) for all patients at diagnosis. ${ }^{10}$ Countries with limited resources, such as Brazil, do not follow this practice and DST is only recommended for special cases, such as retreatment after failure, relapse, patients with suspected primary resistance and case contacts of resistant tuberculosis. ${ }^{11}$ In this study, we have only reported the DST results of the isolates of those patients who had this test requested.

\subsection{IS6110 restriction fragment length polymorphism (RFLP) analysis}

Genomic DNA isolation and P vuII IS6110RFLP analysis was performed according to standardized methods. ${ }^{12}$

The IS6110 RFLP band patterns were analyzed by the Bio-Numerics software version 6.5 (Applied Maths - Belgium). A dendrogram was constructed to show the degree of similarity among the isolates by un-weighted pair group method of arithmetic average (UPGMA) and the Dice index (1.0\% tolerance, $1.5 \%$ optimization). The analysis was done in 3-year and 11-year windows. Two or more strains with indistinguishable RFLP patterns (fingerprint) were defined to belong to the same RFLP cluster. Strains with RFLP patterns shown to be at least $70 \%$ similar were defined to belong to the same family.

Simpson's diversity index was used to calculate the relative frequencies of different number of IS 6110 RFLP genotypes in $\mathrm{RD}^{\text {Rio }}$ and non-RD ${ }^{\text {Rio }}$ groups. ${ }^{13}$

\subsection{Spoligotyping}

All Mtb isolates were also submitted to spoligotyping analysis by a commercial kit (Ocimum Biosolutions Inc., India) according to a standard protocol. ${ }^{14,15}$ The results were recorded in a 43 -digit binary format representing the 43 spacers. The spoligotyping patterns were compared with an updated SpolDB $4^{15}$ database - SITVIT WEB ${ }^{16}$ of Pasteur Institute of Guadeloupe (http//:www.pasteur-guadeloupe.fr: 8081/SITVIT_ONLINE) that provides information on the Mtb spoligotypes worldwide. The orphan patterns were analyzed by the algorithm, SPOTCLUST, ${ }^{17}$ to identify the probability of a strain to belong to spoligotype families, based on their spoligotyping patterns.

\subsection{Long sequence polymorphism (LSP)}

A multiplex PCR adapted from Gibson et al. ${ }^{18}$ was performed to differentiate isolates belonging to the $\mathrm{RD}^{\mathrm{Rio}}$ lineage. The PCR reaction was performed in a final volume of 25 $\mu \mathrm{L}$, containing 20 pmol of primers BridgeF: $5^{\prime}$ - CAC TCC GGC TGC CAA TCT CGT C 3', BridgeR: 5' - CAC CGC GAG GCT GAA TGA GAC CA - 3', IS1561F: 5' - GAC CTG ACG CCG CTG ACA C -3', IS1561R: $5^{\prime}$ - CAC CTA CAC CGC TTC CTG CC $3^{\prime} ; 1 \mathrm{U}$ Taq polymerase (Invitrogen Life Technologies, USA), buffer $1 \mathrm{X}, \mathrm{MgCl}_{2} \mathrm{MgCl}_{2} 2.0$ $\mathrm{mM}$, DMSO 5\%, dNTP $0.2 \mathrm{mM}$ deionized water and $20 \mathrm{ng}$ of genomic DNA. The amplification was done in a GeneAmp PCR System 2400 thermocycler (Perkin Elmer, USA). The cycle conditions were $95^{\circ} \mathrm{C}$ for $10 \mathrm{~min}$, followed by 35 cycles at $95^{\circ} \mathrm{C}$ for 1 min, $60{ }^{\circ} \mathrm{C}$ for $1 \mathrm{~min}$ and $72{ }^{\circ} \mathrm{C}$ for $4 \mathrm{~min}$, and a final extension at $72{ }^{\circ} \mathrm{C}$ for $10 \mathrm{~min}$. The PCR products were detected in $1.5 \%$ agarose gel treated with ethidium bromide, under UV transillumination. The identification of $\mathrm{RD}^{\mathrm{Rio}}$ or non-RD ${ }^{\mathrm{Rio}}$ strains genotypes was established according to a PCR product band size; the presence of a band of $1175 \mathrm{bp}$ indicated $\mathrm{RD}^{\mathrm{Rio}}$ and a band of $530 \mathrm{bp}$ indicated non-RD ${ }^{\mathrm{Rio}}$ strains.

\subsection{Statistics analysis}

Covariates were divided into two subgroups: demographic factors (e.g., age, race/ethnicity, gender, educational level) and clinical factors (e.g., symptoms and existing medical conditions). Odds ratios (OR) along with the $95 \%$ confidence intervals (CI) and $p$-value 
were estimated. In addition, univariate logistic regression was performed for each variable of interest and OR with a $p$-value $<0.10$ were included in the multivariate logistic regression for calculation of adjusted odds ratios for clustered isolates. Two models were created to show differences between variables. In the first model, the outcome was set up with clustered isolates; in the second model, the outcome was set up with $\mathrm{RD}^{\text {Rio }}$ genotypes. All analyses were conducted with the Stata ${ }^{\circledR}$ statistical package, Version 9 (StataCorp, College Station, TX, 2001).

\section{Results}

Between January 2000 and December 2010, 5470 TB patients were diagnosed in the metropolitan area of Vitória. Here, only patients with a positive culture and with bacteriological confirmation for Mtb were included in this study. Good quality RFLP patterns were obtained from isolates from 981 patients (Figure 1).

Demographic, clinical and diagnostic characteristics for all patients are summarized in Table 1 and stratified by RFLP cluster pattern association. The median age of participants was 36 years and the majority was male and non-White. There was no difference between RFLP cluster and non-cluster isolates related to gender, race, educational level, residence and age $(p>0.05)$.

The results of RFLP analysis in the 3-year and 11-year windows are shown in Figure 2. DST was done for 338 isolates. Among these, 13 (7\%) of 180 clustered isolates were resistant to at least one drug and; while $17(11 \%)$ of 158 non-clustered isolates were resistant to at least one drug ( $p=0.2$, Chi-square test). The $\mathrm{RD}^{\text {Rio }}$ analysis showed that $13(10 \%)$ of $128 \mathrm{RD}^{\text {Rio }}$ isolates were resistant to at least one drug and; while 17 (8\%) of 203 non-RD ${ }^{\text {Rio }}$ isolates were resistant to at least one drug $(p=0.58$, Chi-square test). Of 30 resistant isolates, 7 (2\%) were multidrug resistant (MDR); 2 (0.6\%) of them were $\mathrm{RD}^{\text {Rio }}$ and $5(1.4 \%)$ were non$\mathrm{RD}^{\text {Rio }}$ genotype.

We obtained chest X-ray information from 878 (90\%) of the cases; $865(99 \%)$ had pulmonary TB. Of these, 377 (44\%) and 488 (56\%) were infected with Mtb strains belonging to an RFLP cluster and a non-cluster pattern, respectively $(p=0.38)$. Among the 681 acid-fast bacilli (AFB) sputum smear test-positive patients, 312 (46\%) and $369(54 \%)$ belonged to cluster patterns, while among 215 sputum smear test-negative patients, 80 (37\%) and $135(63 \%)$ were infected with Mtb strains belonging to a cluster and a non-cluster pattern, respectively (OR $=1.42 ; 95 \% \mathrm{CI}: 1.03-1.98 ; p=0.026)$.

Multivariate analysis revealed that only $\mathrm{RD}^{\text {Rio }}$ genotype strains $\left(\mathrm{OR}_{\mathrm{adj}} 1.52\right.$; $95 \%$ CI: 1.12 $2.05)$ and $\mathrm{Mtb}$ isolates from smear-positive sputum samples ( $\mathrm{OR}_{\mathrm{adj}} 1.50 ; 95 \% \mathrm{CI}: 1.01-$ 2.21) were significantly likely to belong to RFLP clusters.

Among 981 isolates, 375 (38\%) were $\mathrm{RD}^{\text {Rio }}$ and 594 (61\%) were non-RD Rio strains; 12 $(1 \%)$ isolates had two bands by multiplex PCR, indicating a mixed population. Of the 375 $\mathrm{RD}^{\text {Rio }}$ and 594 non-RD ${ }^{\text {Rio }}$ isolates, $180(48 \%)$ and 235 (40\%) belonged to an RFLP cluster, respectively ( $p=0.022$, Chi-square test; OR $=1.35,95 \%$ CI:1.04-1.77) as shown in Table 2 . We found in the univariate analysis that patients infected with $\mathrm{RD}^{\text {Rio }}$ were more likely to have pulmonary disease $(\mathrm{OR}=2.75 ; 95 \% \mathrm{CI}$ : $1.63-4.83 ; p=0.0001)$.

Multivariate analysis revealed that clustered isolates ( $\mathrm{OR}_{\mathrm{adj}} 1.46$; $\left.95 \% \mathrm{CI}: 1.12-1.90\right)$ and pulmonary disease $\left(\mathrm{OR}_{\mathrm{adj}} 2.9\right.$; $\left.95 \% \mathrm{CI}: 1.74-4.85\right)$ were significantly associated with $\mathrm{RD}^{\mathrm{Rio}}$ genotype. Genotyping by IS 6110 RFLP showed that the $180 \mathrm{RD}^{\text {Rio }}$ isolates in clusters belonged to 45 distinct IS 6110 RFLP genotypes while the 235 non-RD ${ }^{\text {Rio }}$ clustered isolates

Tuberculosis (Edinb). Author manuscript; available in PMC 2014 March 01. 
were comprised of 75 distinct genotypes $(p=0.30)$. Simpson's diversity index for $\mathrm{RD}^{\text {Rio }}$ was 0.96 and for non- $\mathrm{RD}^{\text {Rio }}$ was 0.98 , indicating great diversity in both groups.

Spoligotype data were obtained from 619 isolates (63\%) (Supplementary Figure 1); 530 could be defined to the SIT level while 89 had orphan patterns. In addition, $384(62 \%)$ were of the non-RD ${ }^{\text {Rio }}$ genotype, $225(36 \%)$ of the $\mathrm{RD}^{\text {Rio }}$ genotype and $10(2 \%)$ were of mixed genotypes, similar to the distribution found with the RFLP analysis. Spoligotyping family and SIT information are presented in Table 3. We also observed $\mathrm{RD}^{\text {Rio }}$ among 2 isolates defined as T (1\%), 5 as Haarlem (2\%), 6 (3\%) as unknown families and 20 orphan genotypes $(9 \%)$.

\section{Discussion}

Several studies have reported the use of genotyping tests to characterize bacterial population structure of Mtb strains and their transmission in defined communities. A high prevalence of TB caused by identical or related Mtb lineages in a community could represent recent introduction or enhanced virulence of such strains, or some epidemiologic factors that facilitate increased transmission of such strains. Whether a genetic makeup of Mtb strains is a determinant of TB transmission or severity of disease is often difficult to assess because of limited clinical data. ${ }^{19}$

Lazzarini et al. in 2007 described Mtb $\mathrm{RD}^{\text {Rio }}$ genotype as a clonally-derived sublineage within the LAM family, characterized by a deletion of a $26.3-\mathrm{kb}$ region that included 10 genes. ${ }^{7}$ The Mtb RD ${ }^{\text {Rio }}$ sublineage is the most prevalent cause of TB in Rio de Janeiro and is also present in other Brazilian and world regions ${ }^{7-9}$ The high prevalence in Rio de Janeiro of this $\mathrm{RD}^{\text {Rio }}$ lineage and its association with more severe disease and cavitary lung lesions suggested enhanced virulence of strains belonging to this lineage..$^{7-9}$

As far as we know, this study in Espírito Santo is the first population-based study to determine the incidence of $\mathrm{RD}^{\mathrm{Rio}}$ in a Brazilian population and the largest number of strains analyzed by RFLP typing in a single study in Brazil. The prevalence of TB caused by Mtb $\mathrm{RD}^{\mathrm{Rio}}$ in Espírito Santo was found to be $38 \%$, similar to other studies. However, the other studies were based on convenience clinical isolates collected in hospitals and TB reference laboratories. ${ }^{8}$

In contrast to most studies done in Brazil, our study found that $6 \%$ of the $\mathrm{RD}^{\text {Rio }}$ isolates belonged to spoligotyping families other than LAM and this was also reported by Weisenberg et al. ${ }^{9}$

In the univariate and multivariate analysis, $\mathrm{RD}^{\text {Rio }}$ genotype strains were significantly more likely to belong to RFLP cluster patterns than non-RD ${ }^{\text {Rio }}$ strains, indicating $\mathrm{TB}$ caused by $\mathrm{RD}^{\mathrm{Rio}}$ were more likely to represent recent transmission. Isolates from AFB smear-positive patients were also more likely to belong to RFLP cluster patterns. Several studies have demonstrated that patients who have cavitary lung disease or positive AFB smears in sputum are indeed high transmitters, and hence such strains may be more overly represented in communities. ${ }^{20,21}$

Studies published after 1999 have generally used more than one genotyping method to demonstrate clustering. ${ }^{22-24}$ The use of only one high-resolution typing method (IS6110 RFLP) for a subset of the samples is one limitation of our present study.

Nevertheless, the findings of the analysis of RFLP in this study showed that the percentage of clustering is dependent on the number of Mtb isolates analyzed. The proportion of clustering increases as the number of isolates in each year window period increases, as 
reported by van Soolingen et al. ${ }^{25}$ As seen in Figure 2, the proportion of strains with clustered RFLP patterns during the period (2003-2005) with the highest number (518) of isolates was similar to that found for all the isolates (981) obtained during the entire 11-year period.

The fact that we found a greater proportion $\mathrm{RD}^{\text {Rio }}$ genotypes to belong to RFLP cluster patterns could mean the following: (i) that the $\mathrm{RD}^{\mathrm{Rio}}$ strains are more biologically "fit", as suggested by Lazzarini et al., ${ }^{8}$ or (ii) that these strains were recently introduced into this region of Brazil and evolved after the introduction. $\mathrm{RD}^{\mathrm{Rio}}$ was previously reported to be associated with more severe $\mathrm{TB},{ }^{8}$ but in our study, we observed that it was less likely to cause extrapulmonary disease than non-RD ${ }^{\text {Rio }}$ strains.

Although the proportion of cluster patterns among $\mathrm{RD}^{\mathrm{Rio}}$ strains (48\%) was significantly greater than that among non-RD Rio strains $(40 \%)$, it is not clear if this difference could be attributed to enhanced virulence or transmissibility of the $\mathrm{RD}^{\text {Rio }}$ strains. The RFLP genotypes showed a high level of diversity in both $\mathrm{RD}^{\mathrm{Rio}}$ (Simpson's diversity index $=0.96$ ) and non-RD Rio strains (Simpson's diversity index $=0.98$ ), indicating both groups of Mtb strains were highly heterogeneous. Most of the isolates included in the previous study in Rio de Janeiro were obtained from patients with clinically suspected "complicated" TB, advanced disease, or associated comorbidities, which might have contributed to the association of $\mathrm{RD}^{\text {Rio }}$ genotypes with a more "severe" disease. ${ }^{8}$ From a public health and TB control perspective, if $40-48 \%$ of new TB cases in a community are resulting from recent transmission, the new cases that may be attributed some biologic factors (possibly 8\%) appear to be quite small. The priority of TB control program in Espírito Santo should emphasize programs to identify epidemiologic factors that facilitate enhanced transmission so that such factors could be eliminated.

\section{Supplementary Material}

Refer to Web version on PubMed Central for supplementary material.

\section{Acknowledgments}

We would like to acknowledge the Conselho Nacional de Desenvolvimento Científico e Tecnológico -CNPq by Edital MCT/CNPq/MS-SCTIE-DECIT N ${ }^{\circ}$ 25/2006 - Doenças negligenciadas, National institute of Health on the ICHORTA grant \# 5 U2R TW006883-02 and ENSP-011-LIV-10-2-3.We thank Dr. Valdério do Valle Dettoni for helping with the medical files. We are also grateful to João Batista Pereira da Silva for technical laboratory support.

\section{Appendix A. Supplementary data}

Supplementary data related to this article can be found at http://dx.doi.org/10.1016/j.tube. 2012.09.001.

\section{References}

1. Guia para tratamento da tuberculose para o Programa de Saúde da Família. Brasília (DF): 2002. Ministério da Saúde.

2. Advisory Council for the Elimination of Tuberculosis. Essential components of a tuberculosis prevention and control program recommendations of the Advisory Council for the elimination of tuberculosis. MMWR Morb Mortal Wkly Rep. 1995; 44(RR-11):1-16. [PubMed: 7799912]

3. Vieira RC, Prado TN, Siqueira MG, Dietze R, Maciel EL. Spatial distribution of new tuberculosis cases in Vitória, state of Espírito Santo, between 2000 and 2005. Rev Soc Bras Med Trop. 2008; 41(3):82-86. [PubMed: 18368278]

4. Maciel EL, Pan W, Dietze R, Peres RL, Vinhas SA, Ribeiro FK, Palaci M, Rodrigues RR, Zandonade E, Golub JE. Spatial patterns of pulmonary tuberculosis incidence and their relationship 
to socio-economic status in Vitória, Brazil. Int J Tuberc Lung Dis. 2010; 14(11):1395-1402. [PubMed: 20937178]

5. Alland D, Kalkut GE, Moss AR, et al. Transmission of tuberculosis in New York City. An analysis by DNA fingerprinting and conventional epidemiologic methods. N Engl J Med. 1994; 330(24): 1710-1716. [PubMed: 7993412]

6. Small PM, Hopewell PC, Singh SP, et al. The epidemiology of tuberculosis in San Francisco -a population-based study using conventional and molecular methods. N Engl J Med. 1994; 330(24): 1703-1709. [PubMed: 7910661]

7. Lazzarini LCO, Huard RC, Boechat NL, Gomes HM, Oelemann MC, Kurepina N, Shashkina E, Mello FQ, Gibson AL, Virginio MJ, Marsico AG, Butler WR, Kreiswirth BN, Suffys PN, Lapa e Silva JR, Ho JL. Discovery of a novel Mycobacterium tuberculosis lineage that is a major cause of tuberculosis in Rio de Janeiro, Brazil. J Clin Microbiol. 2007; 45(12):3891-3902. [PubMed: 17898156]

8. Lazzarini LCO, Spindola SM, Bang H, Gibson AL, Weisenberg S, Carvalho WS, Augusto CJ, Huard RC, Kritski AL, Ho JL. RD RIO Mycobacterium tuberculosis infection is associated with a higher frequency of cavitary pulmonary disease. J Clin Microbiol. 2008; 46(7):2175-2183. [PubMed: 18463217]

9. Weisenberg SA, Gibson AL, Huard RC, Kurepina N, Bang H, Lazzarini LC, Chiu Y, Li J, Ahuja S, Driscoll J, Kreiswirth BN, Ho JL. Distinct clinical and epidemiological features of tuberculosis in New York City caused by the RDRio Mycobacterium tuberculosis sublineage. Infect Genet Evol. 2012; 12(4):664-670. [PubMed: 21835266]

10. WHO (World Health Organization). Global TB control. 2011. Available at: http:// www.whglibdoc.who.int/publications/2011//9789241564380_eng.pdf

11. BRASIL. Manual nacional de vigilância laboratorial da tuberculose e outras micobactérias. Ministério da Saúde: Secretaria de Vigilância em Saúde, Departamento de Vigilância Epidemiológica; 2008. Available at: http://portal.saude.gov.br/portal/arquivos/pdf/ manual_laboratorio_tb.pdf

12. van Embden JD, Cave MD, Crawford JT, Dale JW, Eisenach KD, Gicquel B, Hermans P, Martin C, McAdam R, Shinnick TM, Small PM. Strain identification of Mycobacterium tuberculosis by DNA fingerprinting: recommendations for a standardized methodology. J Clin Microbiol. 1993; 31(12):406-409. [PubMed: 8381814]

13. Hunter PR, Gaston MA. Numerical index of the discriminatory ability of typing systems: an application of Simpson's index of diversity. J Clin Microbiol. 1988 Nov; 26(11):2465-2466. [PubMed: 3069867]

14. Kamerbeek J, Schouls L, Kolk A, Van Agterveld M, Van Soolingen D, Kuijper S, Bunschoten A, Molhuizen H, Shaw R, Goyal M, Van Embden J. Simultaneous detection and strain differentiation of Mycobacterium tuberculosis for diagnosis and epidemiology. J Clin Microbiol. 1997; 35(4): 907-914. [PubMed: 9157152]

15. Brudey K, Driscoll R, Rigouts L, Prodinger W, Gori A, Al-Hajoj SA. Mycobacterium tuberculosis complex genetic diversity: mining the fourth international spoligotyping database (SpolDB4) for classification, population genetics and epidemiology. BMC Microbiol. 2006; 6:23. [PubMed: 16519816]

16. Demay C, Liens B, Burguière T, Hill V, Couvin D, Millet J, Mokrousov I, Sola C, Zozio T, Rastogi N. SITVITWEB - a publicly available international multimarker database for studying Mycobacterium tuberculosis genetic diversity and molecular epidemiology. Infect Genet Evol. 2012; 12(4):755-766. [PubMed: 22365971]

17. Vitol I, Driscoll J, Kreiswirth B, Kurepina N, Bennett KP. Identifying Mycobacterium tuberculosis complex strain families using spoligotypes. Infect Genet Evol. 2006; 6(6):491-504. [PubMed: 16632413]

18. Gibson AL, Huard RC, Gey van Pittius NC, Lazzarini LCO, Driscoll J, Kurepina N, Zozio T, Sola C, Spindola SM, Kritski AL, Fitsgerald D, Kremer K, Mardassi H, Chitale P, Viedma GD, Gicquel B, Pape JW, van Soolingen D, Kreiswirth BN, Warren RM, van Helden PD, Rastogi N, Suffys PN, Lapa e Silva JR, Ho JL. Application of sensitive and specific molecular methods to uncover global dissemination of the major RD ${ }^{\text {Rio }}$ sublineage of Latin American-Mediterranean Mycobacterium tuberculosis spoligotype family. J Clin Microbiol. 2008; 46(4):1259-1267. [PubMed: 18234868] 
19. Coscolla M, Gagneux S, Does M. tuberculosis genomic diversity explain disease diversity? Drug Discov Today Dis Mech. 2010; 7(1):e43-e49. [PubMed: 21076640]

20. Shaw JB, Wynn-Williams N. Infectivity of pulmonary tuberculosis in relation to sputum status. Am Rev Tuberc. 1954; 69(5):724-732. [PubMed: 13148535]

21. Behr MA, Warren SA, Salamon H, Hopewell PC, Ponce de Leon A, Daley CL, Small PM. Transmission of Mycobacterium tuberculosis from patients smearnegative for acid-fast bacilli. Lancet. 1999; 353(9151):444-449. Erratum in: Lancet 1999; 353(9165):1714. [PubMed: 9989714]

22. Niemann S, Richter E, Rüsch-Gerdes S. Stability of Mycobacterium tuberculosis IS6110 restriction fragment length polymorphism patterns and spoligotypes determined by analyzing serial isolates from patients with drug-resistant tuberculosis. J Clin Microbiol. 1999; 37(2):409-412. [PubMed: 9889229]

23. Lari N, Rindi L, Bonanni D, Rastogi N, Sola C, Tortoli E, Garzelli C. Three-year longitudinal study of genotypes of Mycobacterium tuberculosis isolates in Tuscany, Italy. J Clin Microbiol. 2007; 45(6):1851-1857. [PubMed: 17460055]

24. Pérez-Lago L, Herranz M, Lirola MM, INDAL-TB GroupBouza E, García de Viedma D. Characterization of microevolution events in Mycobacterium tuberculosis strains involved in recent transmission clusters. J Clin Microbiol. 2011; 49(11):3771-3776. [PubMed: 21940467]

25. van Soolingen D, Borgdorff MW, de Haas PE, Sebek MM, Veen J, Dessens M, Kremer K, van Embden JD. Molecular epidemiology of tuberculosis in the Netherlands: a nationwide study from 1993 through 1997. J Infect Dis. 1999; 180(3):726-736. [PubMed: 10438361] 


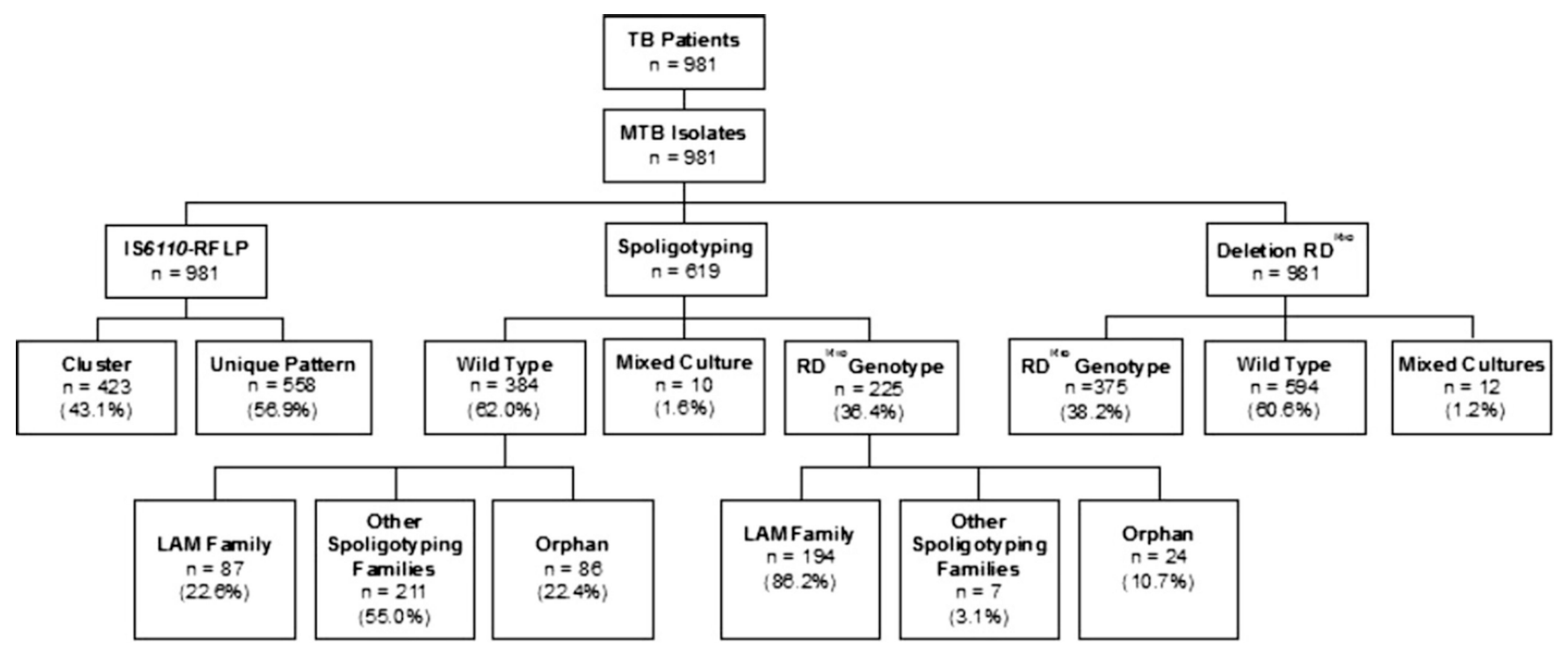

Figure 1.

Flow chart of number of isolates and genotyping methods. 


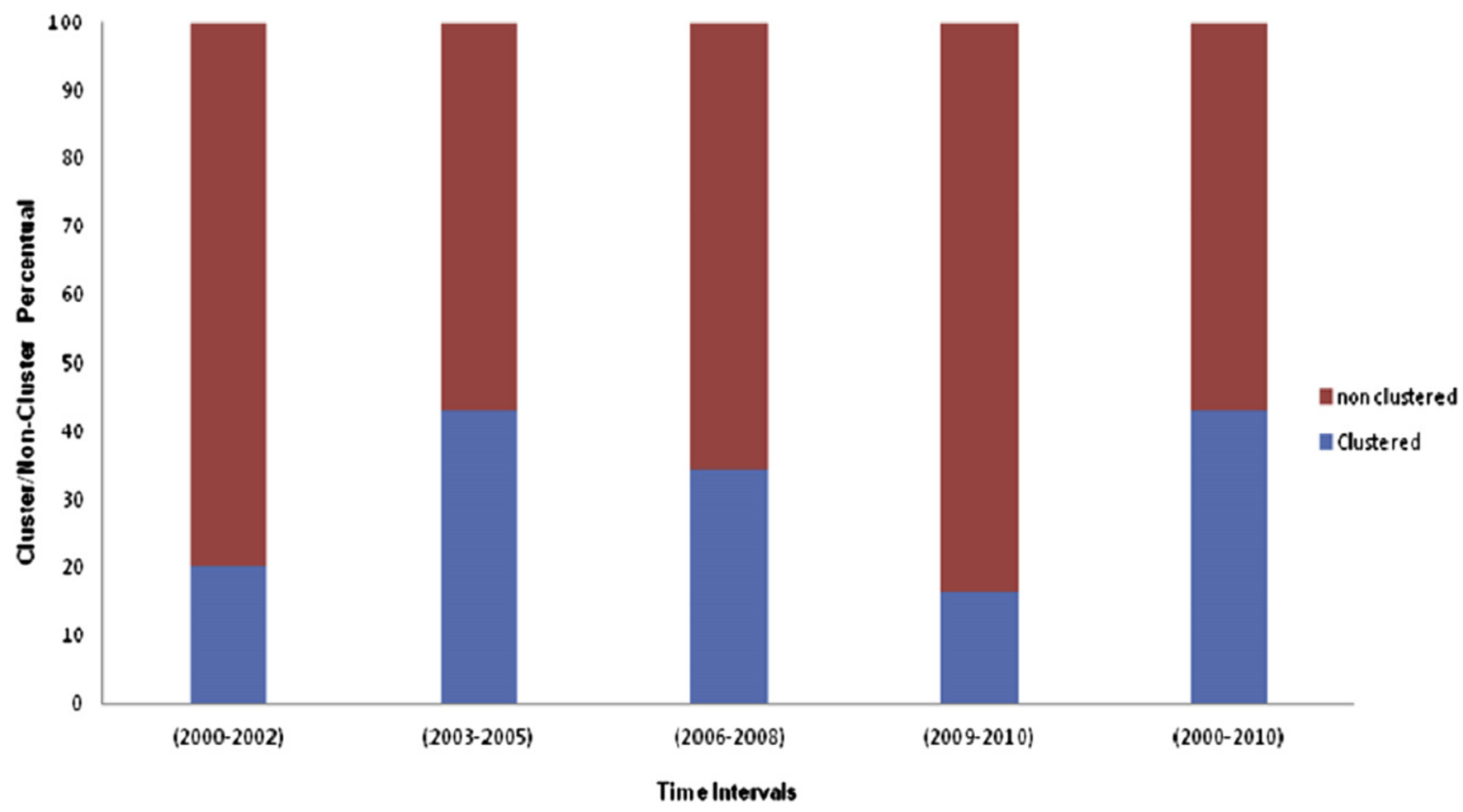

Figure 2.

Percentage of RFLP type clustering of isolates at differential time intervals. 


\section{Table 1}

Demographic and clinical characteristics of TB patients according to their Mtb isolates' IS6110 RFLP cluster patterns in the metropolitan area of Vitória, Brazil, 2000-2010.

\begin{tabular}{|c|c|c|c|c|}
\hline & $\begin{array}{r}\text { Clustered } \\
\text { isolates }(\%)\end{array}$ & $\begin{array}{r}\text { Non-clustered } \\
\text { isolates }(\%)\end{array}$ & OR $(95 \% \mathrm{CI})$ & $p$-value \\
\hline \multicolumn{5}{|l|}{ Gender } \\
\hline Female & $125(43 \%)$ & $169(57 \%)$ & $0.97(0.72-1.28)$ & 0.81 \\
\hline Male & $298(43 \%)$ & $389(57 \%)$ & & \\
\hline \multicolumn{5}{|l|}{ Race } \\
\hline White & $82(40 \%)$ & $123(60 \%)$ & $0.81(0.57-1.15)$ & 0.81 \\
\hline Non-White & $214(45 \%)$ & $261(55 \%)$ & & \\
\hline \multicolumn{5}{|l|}{ Municipality } \\
\hline Vitória city & $267(45 \%)$ & $332(55 \%)$ & $1.18(0.90-1.55)$ & 0.21 \\
\hline Other cities & $153(40 \%)$ & $225(60 \%)$ & & \\
\hline \multicolumn{5}{|l|}{ Age } \\
\hline Mean (SD) & $36.17(13.85)$ & $37.61(13.87)$ & - & 0.11 \\
\hline \multicolumn{5}{|l|}{ TST } \\
\hline Positive $=10 \mathrm{~mm}$ & $365(50 \%)$ & $370(50 \%)$ & $0.89(0.50-1.57)$ & 0.67 \\
\hline Negative $<10 \mathrm{~mm}$ & $31(52 \%)$ & $28(48 \%)$ & & \\
\hline \multicolumn{5}{|l|}{ HIV } \\
\hline Positive & $45(41 \%)$ & $65(59 \%)$ & $0.91(0.59-1.40)$ & 0.19 \\
\hline Negative & $303(43 \%)$ & $400(57 \%)$ & & \\
\hline \multicolumn{5}{|l|}{ TB presentation } \\
\hline Pulmonary & $377(44 \%)$ & $488(56 \%)$ & $1.25(0.77-1.89)$ & 0.38 \\
\hline Extra-pulmonary & $39(39 \%)$ & $61(61 \%)$ & & \\
\hline \multicolumn{5}{|l|}{ Smear results } \\
\hline Positive & $312(46 \%)$ & $369(54 \%)$ & $1.42(1.03-1.98)$ & 0.026 \\
\hline Negative & $80(37 \%)$ & $135(63 \%)$ & & \\
\hline \multicolumn{5}{|l|}{ Genotype } \\
\hline $\mathrm{RD}^{\text {Rio }}$ & $180(48 \%)$ & $196(52 \%)$ & $1.35(1.04-1.77)$ & 0.02 \\
\hline Non-RD ${ }^{\text {Rio }}$ & $235(40 \%)$ & $358(60 \%)$ & & \\
\hline
\end{tabular}

$\mathrm{OR}=$ odds ratio; $\mathrm{CI}=$ confidence interval. 
Table 2

Demographic and clinical characteristics of patients infected with $\mathrm{RD}^{\text {Rio }}$ or non- $\mathrm{RD}$ Rio Mtb strains in the metropolitan area of Vitória, Brazil, 2000-2010.

\begin{tabular}{|c|c|c|c|c|}
\hline & $\begin{array}{r}\mathbf{R D}^{\text {Rio }} \\
\text { isolates }(\%)\end{array}$ & $\begin{array}{l}\text { Non-RD } \\
\text { isolates }(\%)\end{array}$ & OR $(95 \% \mathrm{CI})$ & $p$-value \\
\hline \multicolumn{5}{|l|}{ Gender } \\
\hline Female & $117(40 \%)$ & $176(60 \%)$ & $1.07(0.81-1.44)$ & 0.59 \\
\hline Male & $258(38 \%)$ & $419(62 \%)$ & & \\
\hline \multicolumn{5}{|l|}{ Race } \\
\hline White & $73(36 \%)$ & $131(64 \%)$ & $0.85(0.61-1.19)$ & 0.34 \\
\hline non-White & $302(39 \%)$ & $464(61 \%)$ & & \\
\hline \multicolumn{5}{|l|}{ Municipality } \\
\hline Vitória & $231(39 \%)$ & $363(61 \%)$ & $1.02(0.77-1.34)$ & 0.85 \\
\hline Other cities & $144(38 \%)$ & $232(62 \%)$ & & \\
\hline \multicolumn{5}{|l|}{ Age } \\
\hline Mean (SD) & $36.7(13.35)$ & $371(14.26)$ & - & 0.68 \\
\hline \multicolumn{5}{|l|}{ TST } \\
\hline Positive $=10 \mathrm{~mm}$ & $365(50 \%)$ & $370(50 \%)$ & $0.89(0.50-1.57)$ & 0.67 \\
\hline Negative $<10 \mathrm{~mm}$ & $31(53 \%)$ & $28(47 \%)$ & & \\
\hline \multicolumn{5}{|l|}{ HIV } \\
\hline Positive & $37(35 \%)$ & $70(65 \%)$ & $0.83(0.53-1.29)$ & 0.40 \\
\hline Negative & $271(39 \%)$ & $427(61 \%)$ & & \\
\hline \multicolumn{5}{|l|}{ TB presentation } \\
\hline Pulmonary & $351(41 \%)$ & $503(59 \%)$ & $2.75(1.63-4.83)$ & 0.0001 \\
\hline Extra-pulmonary & $20(20 \%)$ & $79(80 \%)$ & & \\
\hline \multicolumn{5}{|l|}{ Smear results } \\
\hline Positive & $264(39 \%)$ & $409(61 \%)$ & $1.04(0.75-1.45)$ & 0.79 \\
\hline Negative & $81(38 \%)$ & $131(62 \%)$ & & \\
\hline \multicolumn{5}{|l|}{ RFLP } \\
\hline Clustered isolates & $180(43 \%)$ & $235(57 \%)$ & $1.35(1.04-1.77)$ & 0.022 \\
\hline Non-clustered isolates & $196(35 \%)$ & $358(65 \%)$ & & \\
\hline
\end{tabular}

$\mathrm{OR}=$ odds ratio $\mathrm{CI}=$ confidence interval . 
Table 3

Spoligotyping patterns and frequency of Shared International Type (SIT).

\begin{tabular}{|c|c|c|c|}
\hline Spoligotyping patterns & SIT & Family & Frequency \\
\hline 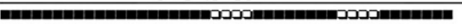 & 42 & LAMO & 76 \\
\hline 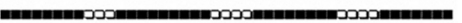 & 33 & LAMB & 39 \\
\hline mannman & 17 & LAND & 38 \\
\hline mane & 20 & LAM1 & 30 \\
\hline 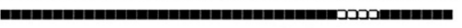 & 53 & $\mathrm{~T} 1$ & 28 \\
\hline 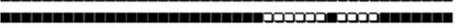 & 47 & $\mathrm{H} 1$ & 20 \\
\hline 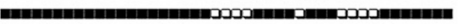 & 64 & LAM6 & 17 \\
\hline 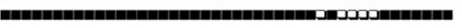 & so & $\mathrm{H} 3$ & 16 \\
\hline mosomanan & 60 & LAM4 & 16 \\
\hline mannang & 177 & LANO & 16 \\
\hline 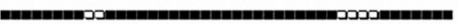 & 34 & $\mathrm{~s}$ & 13 \\
\hline 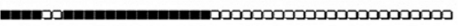 & 2449 & Ambiguous LAMS LAM4 & 10 \\
\hline 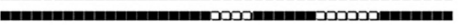 & 1241 & LANG & 9 \\
\hline 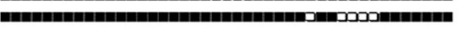 & 167 & $\mathrm{~T} 1$ & 9 \\
\hline 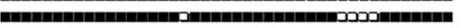 & 119 & $\mathrm{x} 1$ & 9 \\
\hline 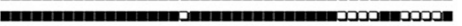 & 137 & $\mathrm{x} 2$ & 8 \\
\hline 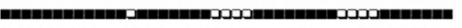 & 93 & LAMS & 7 \\
\hline Insosoming & 95 & LAM6 & 6 \\
\hline 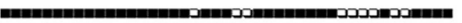 & 39 & T4.CEU & 6 \\
\hline 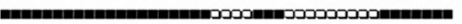 & 2110 & $\mathrm{H} 3$ & 5 \\
\hline " & $\$ 28$ & LAN4 4 & 5 \\
\hline m & 73 & Ambiguous $\mathrm{T} 3 \mathrm{~T} 2$ & 4 \\
\hline 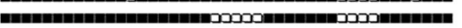 & 230 & LANG & 4 \\
\hline 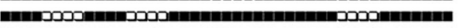 & 1284 & $\mathrm{~T} 1$ & 4 \\
\hline macommanm & 1051 & T1 & 4 \\
\hline 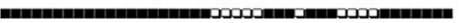 & 228 & T1 & 4 \\
\hline 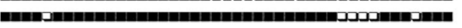 & 153 & $\mathrm{~T}_{2}$ & 4 \\
\hline 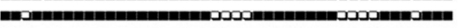 & 1321 & Ambiguous LAM1 LAM4 & 3 \\
\hline 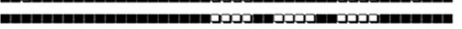 & 59 & $\begin{array}{l}\text { LAM11-ZWE } \\
\text { LWW }\end{array}$ & 3 \\
\hline 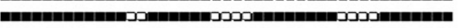 & 216 & LAMS & 3 \\
\hline (E) & 176 & LAM6 & 3 \\
\hline mamomanan & 102 & $\mathrm{~T}$ & 3 \\
\hline 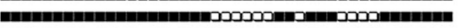 & 306 & T1 & 3 \\
\hline monanana & 291 & $\mathrm{~T} 1$ & 3 \\
\hline mane & 92 & $\mathrm{x}_{3}$ & 3 \\
\hline 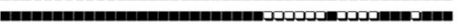 & 62 & $\mathrm{H} 1$ & 2 \\
\hline 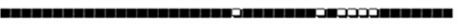 & 741 & $\mathrm{H} 3$ & 2 \\
\hline mosomann= & 2536 & LAM1 & 2 \\
\hline 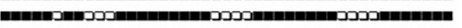 & 2646 & LAMB & 2 \\
\hline 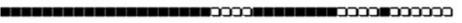 & 1106 & LAM4 4 & 2 \\
\hline 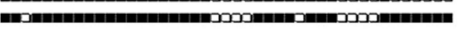 & 1755 & LAM6 & 2 \\
\hline ID & 1758 & LAMO & 2 \\
\hline 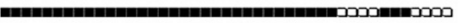 & 51 & $\mathrm{~T} 1$ & 2 \\
\hline manommanm & 1227 & T5_MAD2 & 2 \\
\hline 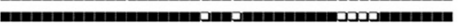 & 58 & T5-MAD2 & 2 \\
\hline 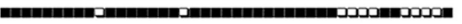 & 439 & $\mathrm{x} 2$ & 2 \\
\hline 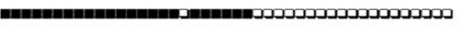 & 450 & Ambiguous $\mathrm{X} 1 \mathrm{TS}$ & 1 \\
\hline 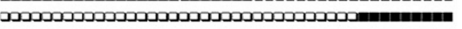 & 1 & Beijing & $i$ \\
\hline 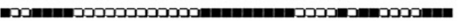 & 1983 & EAI3-ND & 1 \\
\hline 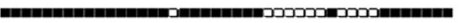 & 571 & H1 & 1 \\
\hline 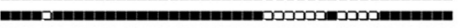 & 382 & $\mathrm{H} 1$ & $i$ \\
\hline 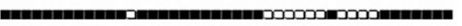 & 218 & $\mathrm{H} 1$ & 1 \\
\hline 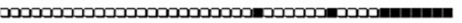 & 2 & $\mathrm{H} 2$ & 1 \\
\hline 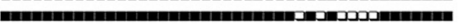 & 746 & $\mathrm{H} 3$ & $i$ \\
\hline 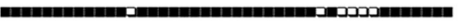 & 36 & H3 & 1 \\
\hline 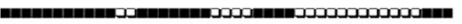 & 2654 & LAM & 1 \\
\hline 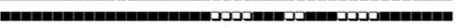 & 2566 & LAM1 & $i$ \\
\hline 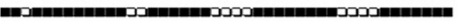 & 2271 & LAM2 & 1 \\
\hline masommanm & 194 & LANR & $i$ \\
\hline 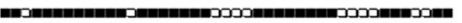 & 179 & LAM2 & 1 \\
\hline mamomannan & 2388 & LAMB & 1 \\
\hline 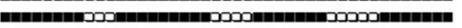 & 1841 & LAMB & $i$ \\
\hline 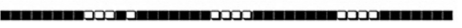 & 211 & LANB & 1 \\
\hline 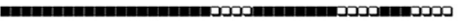 & 163 & LAM4 & 1 \\
\hline 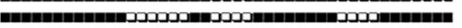 & 1337 & LAMS & $i$ \\
\hline 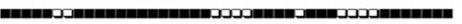 & 1610 & LAM6 & 1 \\
\hline 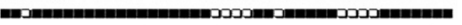 & 1815 & LAMS & 1 \\
\hline Mmo & 2165 & LANO & $i$ \\
\hline 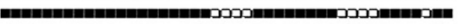 & 1154 & LAMO & 1 \\
\hline 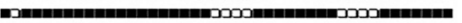 & 866 & LAMP & 1 \\
\hline 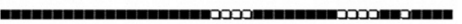 & 162 & LAM & 1 \\
\hline 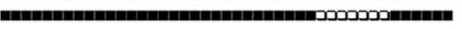 & 2025 & $\mathrm{~T}$ & 1 \\
\hline 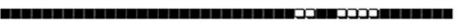 & 1905 & T1 & 1 \\
\hline 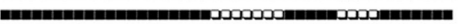 & 1144 & $\mathrm{~T} 1$ & 1 \\
\hline بمدمد & 1122 & $\mathrm{~T} 1$ & 1 \\
\hline 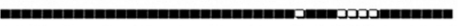 & 462 & $\mathrm{~T} 1$ & 1 \\
\hline 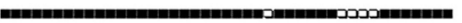 & 122 & $\mathrm{~T} 1$ & 1 \\
\hline manam & 1660 & T2 & 1 \\
\hline 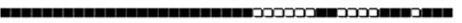 & 233 & $\mathrm{~T} 2$ & 1 \\
\hline 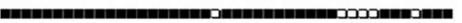 & 175 & T2 & 1 \\
\hline Anannanm & 52 & T2 & 1 \\
\hline & & Total & 488 \\
\hline
\end{tabular}

